\title{
Financial Performance Evaluation of Sport Clubs Traded in Borsa Istanbul by Using Grey Relational Analysis
}

\author{
Ceren Oral ${ }^{1}$ \\ ${ }^{1}$ Department of Economics and Finance, Fethiye Faculty of Management, Mugla Sitk1 Kocman University, \\ Fethiye, Turkey \\ Correspondence: Ceren Oral, Assistant Professor, Department of Economics and Finance, Fethiye Faculty of \\ Management, Mugla Sitkı Kocman University, Fethiye, Turkey. E-mail: ceren.uzar@gmail.com
}

Received: April 9, 2016

doi:10.5539/ijef.v8n5p293
Accepted: April 20, 2016

Online Published: April 25, 2016

URL: http://dx.doi.org/10.5539/ijef.v8n5p293

\begin{abstract}
The aim of this study is to rank the sport clubs registered in Borsa Istanbul based on their financial performances. In this respect the averages of the 5-year-financial-table data from the years 2010-2014 for the enterprises engaged in the subject sector are used. Using the Grey Relational Analysis (GRA) method performance has been measured by means of liquidity, leverage and profitability. Ten financial ratios have been used for the study. Based on the obtained findings, the most significant indicator for measuring the financial performances of the sport clubs is the profitability. Furthermore the sport clubs have also been ranked in the study based on their actual performances.
\end{abstract}

Keywords: grey relational analysis, performance evaluation, financial ratio, sport clubs, Borsa Istanbul

\section{Introduction}

Company performance is a qualitative and quantitative study, which achieves its objective by means of analysis measurement, evaluation and comment, which responds to the questions within a large dimension related with the structure of the company, financial structure and capital structure. Measurement of the company performance is very important both for the executives and for the partners and investors since the company performance enables to determine the extent of the effective use of the sources at hand by a company. Furthermore the increases and decreases in the level of profitability and the status of positive developments in the cost reduction efforts may be understood via performance measurements and evaluations (Kabakç1, 2008; Ecer et al., 2011).

By means of the financial performance analysis, the firms can effectively conduct the functions of making healthy decisions, planning and inspection. In fact the financial performance provides an integral perspective to the performances of the companies (Coşkun, 2007; Aydeniz, 2009). When the academic studies conducted related with the financial performance measurement are examined, it is seen that many different methods are used.

The conventional performance criteria merely based on financial data are not sufficient under the current global competition conditions; and this requires that the non-financial or subjective performance criteria (such as reputation, satisfaction, quality, analysis via little data in uncertain occasions) should also be used for measuring the performance of an enterprise (Kalkan, 2005). In this respect new approaches have been developed, which will enable that analysis via little data in uncertain occasions is also included in the performance measurement. One of these approaches is the GRA included in the Grey Theory.

Grey system theory including the GRA was developed by Deng in 1982 as a new system and is focused on the direction of the relation between two or more components based on the unknown. The GRA, as one of the sub-paragraphs of the Grey System Theory, is one of the methods used for analyzing the uncertainties in multi-criteria decision problems, and in cases of uncertainty provides an easier solution as compared to the mathematical analysis methods. By means of less data, the fundamental relations between the factors of a system can be determined and in this way the restrictive conditions of the conventional techniques are eliminated (Feng \& Wang, 2000).

The most significant advantage of this method is offering solutions to the problems where the number of data is low and the distribution is not normal. Especially recently it has been observed that GRA method is frequently 
used in the field of social sciences (Wang, 2009; Kuo \& Liang, 2011; Golmohammadi \& Mellat-Parast, 2012; Chuang, 2013).

In the study the object is to measure the performances of the sport clubs registered in Borsa Istanbul. The average of the 5-year-financial-table data from the years 2010-2014 has been taken in order to evaluate the performances of the subject sport clubs with GRA method. In line with this objective, hereinafter the study is made up of four parts. The first part is related with the literature review. The second part includes the theoretical descriptions of the methods used in the study. The third part is the stage of implementation where the obtained findings are set forth. In the last part the results and suggestions created based on findings are presented.

\section{Literature Review}

GRA method has been often used to evaluate the financial performance of companies in recent years. Studies performed by using GRA method are summarized below.

Acar (2003) have evaluated the ratios of the enterprise with the reference values determined in the study where he considered the indicators to be used for the measurement and analysis of the financial performance in agricultural enterprises and the reference values and ratios of such indicators.

Wang et al. (2004), have used GRA method for measuring the business operation performances of 10 large airports in Taiwan by means of the financial rations and have considered the factors such as passengers, airline companies and fire extinguishing services.

Chang (2006), has examined the performances of the commercial banks in Taiwan via GRA method. They have concluded that there is an important relationship between the quality of the clients and the financial performance and the largest share in financial performance is occupied by the profitability indicators.

Kung and Kun (2007) have stated that the GRA method is appropriate for evaluating the financial performances of the enterprises and have determined and ranked the financial performances of twenty venture capital companies in Taiwan between 2001 and 2003 using GRA method.

Lin and Wu (2011) used GRA method for analyzing the loan risks of the banking sector in their study. A GRA approach has been developed for generating a financial crisis warning system for the banking sector and an implementation has been performed of a data set of 11 samples.

Baş and Çakmak (2012) have used the GRA method and the logistic regression analysis for determining the financial failure of the enterprises. In the study, the variables used for predicting the financial failure have been considered as the independent variables and have been determined based on their level of significance by means of GRA, wherein the obtained variable set logistic regression analysis was used to develop a model with a classification degree of high precision.

Ayrıçay et al. (2013) have performed the financial evaluations the non-financial firms traded in BIST 30 index using GRA in their studies in BIST. In the study, 23 financial ratios obtained from the financial tables published by the firms in March 2011 have been used.

Bektaş and Tuna (2013) have examined 11 firms based on 6 financial ratios for measurement of the performances of the firms traded in BIST Emerging Companies Market using GRA method.

Ecer and Günay (2014) benefited from GRA method in their studies where they reviewed the financial performances of the tourism firms traded in BIST. 9 firms determined as the alternative set in the study have been examined based on 17 criteria.

Ecer and Böyükaslan (2014) have measured the financial performances of the football clubs in Turkey in 2008-2012 period by means of the ratios and the GRA method.

Kaya (2016) has evaluated the financial performances of the insurance companies other than those for life insurance by means of GRA method considering 2010-2014 period.

\section{Grey Relational Analysis}

GRA has six steps (Zhai et al., 2009).

Step 1: Generation of a decision matrix: the mxn decision matrix is generated as follows, wherein $\mathrm{m}$ indicates the alternatives and $\mathrm{n}$ indicates the criteria: 


$$
\mathrm{X}=\left[\begin{array}{l}
x_{1}(1), x_{1}(2), \ldots x_{1}(n) \\
x_{2}(1), x_{2}(2), \ldots x_{2}(n) \\
\ldots \\
\ldots \\
x_{m}(1), x_{m}(2), \ldots x_{m}(n)
\end{array}\right]
$$

Step 2: Generation of the reference series: A reference series is formed by adding the data of an imaginary company.

Step 3: Generation of the comparison series: The difficulty in comparison of the indicators of different dimension requires standardization of the data. In this step the data are normalized. There are 3 possible outcomes.

In case it is more appropriate that the criteria value is obtained greater after the normalized process, formula (2) should be used,

$$
x_{i}(k)=\frac{x_{i}(k)-\min x_{i}(k)}{\max x_{i}(k)-\min x_{i}(k)}
$$

In case it is more appropriate that the criteria value is obtained smaller after the normalized process, formula (3) should be used,

$$
x_{i}(k)=\frac{\max x_{i}(k)-x_{i}(k)}{\max x_{i}(k)-\min x_{i}(k)}
$$

In case it is more appropriate that the criteria value is obtained as an average value after the normalized process, the formula (4) should be used.

$$
x_{i}(k)=\frac{\left|x_{i}(k)-x_{0}(k)\right|}{\max x_{i}(k)-x_{0}(k)}
$$

Wherein formula (2) is used for converting the benefit values into standard values, formula (3) is used for converting the cost values into standard values and formula (4) is used for converting the average type values into standard values.

Step 4: Generation of the absolute values table: The coefficient differences are calculated based on the characteristics of the criteria. The coefficient difference is the difference between the sequence number and the reference number. It is calculated by means of formula (5).

$$
\Delta x_{i}(k)=\left|x_{0}(k)-x_{i}(k)\right|
$$

Step 5: Generation of the Grey relational coefficient matrix: In Grey relational analysis, Grey relational coefficient $\xi$ can be expressed as follows.

$$
\xi_{i}(k)=\frac{\Delta \min +p \Delta \max }{\Delta x_{i}(k)+p \Delta \max }
$$

In formula (6), $\delta$ is the distinguisher coefficient and is in the $[0,1]$ interval. However it is recommended that it should be taken as 0.5 during transactions.

Step 6: Calculation of the relational degree.

$$
r_{i}=1 / n \sum_{k=1}^{n} \xi_{i}(k)
$$

and then the relational degree follows as:

$$
r_{i}=\sum[w(k) \xi(k)]
$$

\section{Implementation}

In this study the object is to determine the financial performances of sport clubs traded in Borsa Istanbul using the GRA method. For this purpose an exemplification has been created using the financial data of the sport clubs traded in Borsa Istanbul in 2010-2014. According the availability of data, there are four sport clubs. These clubs 
are: Beşiktaş, Fenerbahçe, Galatasaray and Trabzonspor. During analysis stage of the study; in terms of confidentiality of performance data's about sport clubs, codes were used instead of the names of the sport clubs. The codes of sport clubs are respectively A, B, C and D. Four sport clubs in the study was evaluated by 10 criteria. The data used in the study have been obtained from Public Disclosure Platform (www.kap.gov.tr).

The implementation stages of the Grey Relational Analysis have been determined as follows: Determining the financial ratios, creating the decision matrix, creating the reference series, creating the comparison series, creating the absolute value table and creating the grey relational coefficient matrix.

\subsection{Determining the Financial Ratios}

The financial ratios used for the study are shown in Table 1 . These rates render information to the company managers about the precautions to be taken.

Table 1. Financial ratios

\begin{tabular}{ccc}
\hline Type of Ratios & Ratios & Code \\
\hline Liquidity Ratios & Current Assets/Short Term Loans & F1 \\
& Current Assets - Inventories/Short Term Loans & F2 \\
\hline \multirow{2}{*}{ Leverage Ratios } & Long Term Loans/Equity Capital & F3 \\
& Total Debts/Total Assets & F4 \\
& Short Term Loans/Total Debts & F5 \\
& Total Assets/Equity Capital & F6 \\
\hline \multirow{2}{*}{ Profitability Ratios } & Gross Profit/Net Sales & F7 \\
& Net Profit/Net Sales & F8 \\
& Net Profit/Total Assets & F9 \\
\hline
\end{tabular}

\subsection{Generation of the Decision Matrix}

The following decision matrix table has been generated by means of the financial rates calculated based on the data obtained from the balance sheets and income tables of the sport clubs. The decision matrix of the sport clubs are shown in Table 2.

Table 2. Decision matrix of the sport clubs

\begin{tabular}{ccccccccccc}
\hline & F1 & F2 & F3 & F4 & F5 & F6 & F7 & F8 & F9 & F10 \\
\hline A & 0,164 & 0,144 & $-0,574$ & 3,511 & 0,609 & $-0,445$ & $-0,260$ & $-0,783$ & $-0,962$ & 0,402 \\
B & 1,844 & 1,829 & $-0,125$ & 1,129 & 0,706 & 1,376 & 0,149 & $-0,011$ & $-0,088$ & 0,294 \\
C & 0,362 & 0,341 & $-5,814$ & 1,214 & 0,526 & $-13,329$ & $-0,126$ & $-0,473$ & $-0,222$ & 2,324 \\
D & 0,419 & 0,4189 & $-0,463$ & 1,018 & 0,784 & $-2,224$ & $-0,195$ & $-0,261$ & $-0,103$ & 1,449 \\
\hline
\end{tabular}

\subsection{Generating the Reference Series}

By means of creating an imaginary reference company and adding the imaginary values of such an imaginary company, the values stated in Table 3 have been obtained.

Table 3. Decision matrix with generated reference series of the sport clubs

\begin{tabular}{ccccccccccc}
\hline & F1 & F2 & F3 & F4 & F5 & F6 & F7 & F8 & F9 & F10 \\
\hline X & 1,00 & 1,00 & 1,00 & 1,00 & 1,00 & 1,00 & 1,00 & 1,00 & 1,00 & 1,00 \\
A & 0,164 & 0,144 & $-0,574$ & 3,511 & 0,609 & $-0,445$ & $-0,260$ & $-0,783$ & $-0,962$ & 0,402 \\
B & 1,844 & 1,829 & $-0,125$ & 1,129 & 0,706 & 1,376 & 0,149 & $-0,011$ & $-0,088$ & 0,294 \\
C & 0,362 & 0,341 & $-5,814$ & 1,214 & 0,526 & $-13,329$ & $-0,126$ & $-0,473$ & $-0,222$ & 2,324 \\
D & 0,419 & 0,4189 & $-0,463$ & 1,018 & 0,784 & $-2,224$ & $-0,195$ & $-0,261$ & $-0,103$ & 1,449 \\
\hline
\end{tabular}

\subsection{Generation of the Comparison Series}

The company directors and partners always desire that the company profitability and the short term payment capacity is high. Therefore formula (2) has been used for liquidity and profitability ratios. Since the leverage 
ratios indicate the debt burden of the firm, it is desired that such level should be low particularly in terms of the grantor of loans. Therefore the leverage ratios have been calculated by using formula (3). Table 4 shows the comparison series of the sport clubs.

Table 4. Comparison series table of the sport clubs

\begin{tabular}{ccccccccccc}
\hline & F1 & F2 & F3 & F4 & F5 & F6 & F7 & F8 & F9 & F10 \\
\hline X & 1 & 1 & 1 & 1 & 1 & 1 & 1 & 1 & 1 & 1 \\
A & 0 & 0 & 0,079 & 0 & 0,677 & 0,124 & 0 & 0 & 0 & 0,053 \\
B & 1 & 1 & 0 & 0,955 & 0,2995 & 0 & 1 & 1 & 1 & 0 \\
C & 0,018 & 0,117 & 1 & 0,921 & 1 & 1 & 0,328 & 0,402 & 0,846 & 1 \\
D & 0,152 & 0,163 & 0,0595 & 1 & 0 & 0,245 & 0,159 & 0,676 & 0,982 & 0,569 \\
\hline
\end{tabular}

\subsection{Generation of the Absolute Value Table}

In order to find the highest and the lowest values, the absolute value table (Table 5) has been created as follows by using formula (5).

Table 5. Absolute value table for the sport clubs

\begin{tabular}{ccccccccccc}
\hline & F1 & F2 & F3 & F4 & F5 & F6 & F7 & F8 & F9 & F10 \\
\hline X & 1 & 1 & 1 & 1 & 1 & 1 & 1 & 1 & 1 & 1 \\
A & 1 & 1 & 0,921 & 1 & 0,323 & 0,876 & 1 & 1 & 1 & 0,947 \\
B & 0 & 0 & 1 & 0,045 & 0,700 & 1 & 0 & 0 & 0 & 1 \\
C & 0,982 & 0,883 & 0 & 0,079 & 0 & 0 & 0,672 & 0,598 & 0,154 & 0 \\
D & 0,848 & 0,837 & 0,940 & 0 & 1 & 0,755 & 0,841 & 0,324 & 0,018 & 0,431 \\
\hline
\end{tabular}

\subsection{Generation of the Grey Relational Coefficient Matrix Table}

In order to transform all the financial ratios into grey relational coefficient, the grey relational coefficient matrix table has been created as follows (Table 6 ) using formula (7) by taking $\delta=0,5$.

Table 6. Grey relational coefficient matrix table

\begin{tabular}{ccccccccccc}
\hline & F1 & F2 & F3 & F4 & F5 & F6 & F7 & F8 & F9 & F10 \\
\hline A & 0,333 & 0,333 & 0,352 & 0,333 & 0,608 & 0,363 & 0,333 & 0,333 & 0,333 & 0,346 \\
B & 1 & 1 & 0,333 & 0,918 & 0,417 & 0,333 & 1 & 1 & 1 & 0,333 \\
C & 0,337 & 0,361 & 1 & 0,864 & 1 & 1 & 0,427 & 0,455 & 0,765 & 1 \\
D & 0,371 & 0,374 & 0,347 & 1 & 0,333 & 0,398 & 0,373 & 0,607 & 0,966 & 0,537 \\
\hline
\end{tabular}

There are two different conditions for evaluation of the grey relational coefficient matrix. In the first condition the criteria have the same level of importance, which is also the case for the study. In the second conditions the concerned levels are different. Assuming that the criteria have an equal level, the evaluation table (Table 7) including the degree of relationship and the rating of the companies has been created as follows. In Table 7, the numbers within brackets express the rating for each financial ratio.

Table 7. Grey relational coefficient matrix evaluation table

\begin{tabular}{ccccccccccccc}
\hline & F1 & F2 & F3 & F4 & F5 & F6 & F7 & F8 & F9 & F10 & Degree of Relation & Ranking \\
\hline & 0,333 & 0,333 & 0,352 & 0,333 & 0,608 & 0,363 & 0,333 & 0,333 & 0,333 & 0,346 & 0,367 & 4 \\
A & $(4)$ & $(4)$ & $(2)$ & $(4)$ & $(2)$ & $(3)$ & $(4)$ & $(4)$ & $(4)$ & $(3)$ & & \\
\hline & 1,00 & 1,00 & 0,333 & 0,918 & 0,417 & 0,333 & 1,00 & 1,00 & 1,00 & 0,333 & 0,733 & 1 \\
B & $(1)$ & $(1)$ & $(4)$ & $(2)$ & $(3)$ & $(4)$ & $(1)$ & $(1)$ & $(1)$ & $(4)$ & & \\
\hline & 0,337 & 0,361 & 1,00 & 0,864 & 1,00 & 1,00 & 0,427 & 0,455 & 0,765 & 1,00 & 0,721 & 2 \\
C & $(3)$ & $(3)$ & $(1)$ & $(3)$ & $(1)$ & $(1)$ & $(2)$ & $(3)$ & $(3)$ & $(1)$ & & \\
\hline & 0,371 & 0,374 & 0,347 & 1,00 & 0,333 & 0,398 & 0,373 & 0,607 & 0,966 & 0,537 & 0,531 & \\
D & $(2)$ & $(2)$ & $(3)$ & $(1)$ & $(4)$ & $(2)$ & $(3)$ & $(2)$ & $(2)$ & $(2)$ & & \\
\hline
\end{tabular}




\section{Conclusion}

In the study a comparison is performed based on the financial performances of four sport clubs registered in Borsa Istanbul. By means of the implemented method, a rating has been obtained by focusing on the entirety of the ratios instead of examining them individually. In the study each financial ratio has been taken equally with the respective level. Considering the liquidity ratios, the sport clubs with the highest degree are B, D, C and A respectively. Considering the profitability ratios, the sport clubs with the highest degree are B, C, D and A respectively.

Considering all the performance criteria integrally and implementing a general rating among the sport clubs, the sport clubs with the highest degree are B, C, D and A respectively. In this context, the B has the highest performance and $\mathrm{A}$ has the lowest performance. When the liquidity and profitability ratios of company $\mathrm{B}$, which has the best performance in the general rating, are considered, it is observed that company B occupies the top rank. When the liquidity and profitability ratios of company A, which has the worst performance in the general rating, are considered, it is observed that company A occupies the last rank. These results indicate that the liquidity and profitability rates are effective on the general financial performances of the sport clubs. The highest effect is the effect of the profitability ratios. However it is observed that the ranking based on the profitability ratios is identical with the ranking based on the general performance ratios.

The restriction of this study is the fact that all the financial ratios were not considered. This can be improved in the future by means of a study where all the financial ratios are considered. Also by using different and multi-criteria decision making techniques, different performance evaluation studies of the sport clubs may be performed and the results may be compared.

\section{References}

Acar, M. (2003). Tarımsal İşletmelerde Finansal Performans Analizi. Erciyes Üniversitesi İktisadi ve İdari Bilimler Fakültesi Dergisi, 20, 21-37.

Aydeniz, A. S. (2009). Makroekonomik Göstergelerin Firmaların Finansal Performans Ölçütleri Üzerindeki Etkisinin Ölçülmesine Yönelik Bir Araştırma: IMKB’ye Kote Gıda ve İçecek Şirketleri Üzerine Bir Uygulama. Marmara Üniversitesi İktisadi ve İdari Bilimler Fakültesi Dergisi, 27(2), 263-277.

Ayrıçay, Y., Özçalıcı, M., \& Kaya, A. (2013). Gri İlişkisel Analizin Finansal Kıyaslama Aracı Olarak Kullanılmasi: İMKB-30 Endeksindeki Finansal Olmayan Firmalar Üzerine Bir Uygulama. Kahramanmaraş Sütçü Imam Üniversitesi Sosyal Bilimler Dergisi, 10(1), 219-238.

Baş, M., \& Çakmak, Z. (2012). Gri İlişkisel Analiz ve Lojistik Regresyon Analizi ile İşletmelerde Finansal Başarısızlığın Belirlenmesi ve Bir Uygulama. Anadolu Üniversitesi Sosyal Bilimler Dergisi, 12(3), 63-82.

Bektaş, H., \& Tuna, K. (2013). Borsa İstanbul Gelişen İşletmeler Piyasası'nda İşlem Gören Firmaların Gri İlişkisel Analiz ile Performans Ölçümü. Çankırı Karatekin Üniversitesi Fakültesi Dergisi, 3(2), 185-198.

Chang, C. P. (2006). Managing Business Attributes and Performance for Commercial Banks. The Journal of Amerikan Academy of Business, 9(1), 104-109.

Chuang, C. L. (2013). Application of Hybrid Case-Based Reasoning for Enhanced Performance in Bankruptcy Prediction. Information Sciences, 236, 174-185. http://dx.doi.org/10.1016/j.ins.2013.02.015

Coşkun, A. (2007). Stratejik Performans Yönetimi ve Performans Karnesi. İstanbul: Literatür Yayınc1lık.

Deng, J. (1982). Control problems of Grey Systems. System and Control Letters, 1(5), 288-294. http://dx.doi.org/10.1016/S0167-6911(82)80025-X

Ecer, F., \& Boyukaslan, A. (2014). Measuring Performances of Football Clubs Using Financial Ratios: The Gray Relational Analysis Approach. American Journal of Economics, 4(1), 62-71.

Ecer, F., \& Günay, F. (2014). Borsa İstanbul'da İşlem Gören Turizm Şirketlerinin Finansal Performanslarının Gri İlişkisel Analiz Yöntemiyle Ölçülmesi. Anatolia: Turizm Araştırmaları Dergisi, 25(1), 35-48. http://dx.doi.org/10.17123/atad.vol25iss195016

Ecer, F., Ulutagay, G., \& Nasiboglu, E. (2011). Does Foreign Ownership Affect Financial Performance? An Industrial Approach. Middle Eastern Finance and Economics, 14, 152-166.

Feng, C. M., \& Wang, R. T. (2000). Performance Evaluation for Airlines Including the Consideration of Financial Ratios. Journal of Air Transport Management, 6(3), 133-142. http://dx.doi.org/10.1016/S0969-6997(00)00003-X 
Golmohammadi, D., \& Mellat-Parast, M. (2012). Developing a Grey-Based Decisionmaking Model for Supplier Selection. International Journal of Production Economics, 137(2), 191-200. http://dx.doi.org/10.1016/j.ijpe.2012.01.025

Kabakçı, Y. (2008). Sermaye Yapısı ile Şirket Performansı Arasındaki İlişki: Gıda Sektöründe Bir Uygulama. Ege Akademik Bakış, 8(1), 167-182.

Kalkan, A. (2005). Kobilere Sağlanan Desteklerin Örgütsel Performansa Etkileri (Unpublished doctoral dissertation). Gebze Yüksek Teknoloji Enstitüsü Sosyal Bilimler Fakültesi, Gebze, Kocaeli.

Kaya, E. (2016). Financial Performance Assessment of Non-Life Insurance Companies Traded in Borsa Istanbul via Grey Relational Analysis. International Journal of Economics and Finance, 8(4), 277-288. http://dx.doi.org/10.5539/ijef.v8n4p277

Kung, C. Y. W., \& Kun, L. (2007). Applying Grey Relational Analysis and Grey Decision-Making to Evaluate the Relationship Between Company Attributes and Its Financial Performance- A Case Study of Venture Capital Enterprises in Taiwan. Desicion Support Systems, 43(3), 842-852. http://dx.doi.org/10.1016/j.dss.2006.12.012

Kuo, M. S., \& Liang, G. S. (2011). Combining VIKOR with GRA Techniques to Evaluate Service Quality of Airports Under Fuzzy Environment. Expert Systems with Applications, 38(3), 1304-1312. http://dx.doi.org/10.1016/j.eswa.2010.07.003

Lin, S. L., \& Wu, S. J. (2011). Is Grey Relational Analysis Superior to the Conventional Techniques in Predicting Financial Crisis? Expert Systems with Applications, 38(5), 5119-5124. http://dx.doi.org/10.1016/j.eswa.2010.09.139

Retrieved on January 12, 2016 from http://www.kap.gov.tr/sirketler/islem-goren-sirketler/sektorler.aspx

Wang, R. T., Ho, C. H., Feng, C. M., \& Yang, Y. K. (2004). A Comparative Analysis of the Operational Performance of Taiwan's Major Airports. Journal of Air Transport Management, 10(5), 353-360. http://dx.doi.org/10.1016/j.jairtraman.2004.05.005

Wang, Y. J. (2009). Combining Grey Relation Analysis with FMCGDM to Evaluate Financial Performance of Taiwan Container Lines. Expert Systems with Applications, 36(2), 2424-2432. http://dx.doi.org/10.1016/j.eswa.2007.12.027

Zhai, L. Y., Khoo, L. P., \& Zhong, Z. W. (2009). Design Concept Evaluation in Product Development Using Rough Sets and Grey Relation Analysis. Expert System with Applications, 36(3), 7072-7079. http://dx.doi.org/10.1016/j.eswa.2008.08.068

\section{Copyrights}

Copyright for this article is retained by the author(s), with first publication rights granted to the journal.

This is an open-access article distributed under the terms and conditions of the Creative Commons Attribution license (http://creativecommons.org/licenses/by/3.0/). 